\title{
Statyba
}

\section{THE INFLUENCE OF THE RESONANT CEILING WITH THE RECTANGULARSHAPED SLITS ON THE HALL ACOUSTICS}

\section{Stauskis \& V. Stauskis}

To cite this article: V. Stauskis \& V. Stauskis (1996) THE INFLUENCE OF THE RESONANT CEILING WITH THE RECTANGULARSHAPED SLITS ON THE HALL ACOUSTICS, Statyba, 2:8, 104-109, DOI: $10.1080 / 13921525.1996 .10590178$

To link to this article: https://doi.org/10.1080/13921525.1996.10590178

曲 Published online: 01 Nov 2012.

Submit your article to this journal ๘

Џ Article views: 65 


\section{THE INFLUENCE OF THE RESONANT CEILING WITH THE RECTANGULAR- SHAPED SLITS ON THE HALL ACOUSTICS}

\section{Stauskis}

\section{Introduction}

In any music hall, its objective acoustic indicators must always be optimized. These indicators correlate well with the subjective criteria of evaluation of the music sound. The reverberation time is one of the most important objective criteria employed in the evaluation of the hall acoustics. Optimization of the reverberation time is most often necessary at low frequencies, sometimes - at medium frequencies, because at high frequencies the energy is well-absorbed by the air of the hall itself. For this purpose, a certain quantity of sound-absorbing materials must be used. Their absorption coefficients are always frequently-dependent. Therefore, it is important to find constructions that are characterized by good sound absorption at the low frequencies and by poor absorption - at the high frequencies.

Suspended ceilings are always installed in halls. If rectangular slits of various width are left between the planes of such ceiling crosswise the hall, a resonant construction is obtained, which will, in one way or another, absorb the sound energy.

The influence of the resonant suspended ceiling on the hall acoustics may depend on the slit width and form, the distance between the ceiling and the rigid surface, the absorption qualities of the planes of the hall itself etc. We see that the number of factors is quite large and, needless to say, one has no possibility to explore their influence on the hall acoustics in real halls. Therefore, best results may be achieved by the experiments with the physical model of the hall.

The sound absorption properties of such resonators were theoretically analyzed in the works $[1,2]$. The aim of this paper is to determine, by means of an experiment with the physical hall model, how the acoustic indicators are influenced by the resonant suspended ceiling with the rectangular-shaped slits between the ceiling planes.
The peculiarities of physical modelling are described in the work [3].

\section{Results of investigations}

The resonant suspended ceiling with the rectangular-shaped slits between the planes was chosen for the investigation. A schematic cross-section of the hall is represented in Fig. 1.

The lay-out of the suspended ceiling with the rectangular-shaped slits between the planes is shown in Fig. 2.

Within the framework of the investigation into the influence of such ceiling on the hall acoustics, we will measure its reverberation time, the index of music sound clarity, and the acoustic centre of gravity. On the basis of the reverberation time values, the sound absorption coefficients and the overall sound absorption of the hall with the suspended ceiling and without the suspended ceiling will be computed. When computing the reverberation time values from the sound field muffling curves, the question arose as to which point should be taken as the starting point for the evaluation of the sound field muffling. In the computation of the standard reverberation time, the muffling of the sound field is approximated by evaluating the level from $-5 \mathrm{~dB}$ to $-35 \mathrm{~dB}$. However, too narrow dynamic range is obtained at high frequencies. It may be expanded by increasing the impulse power, but it is not sufficient because the resolution of the integrated circuit of a 12-bit transducer is too low. For this reason the sound field muffling was approximated from $-3 \mathrm{~dB}$ to -33 $\mathrm{dB}$. In this case, reliable results are realized in the frequency range from $50 \mathrm{~Hz}$ to $2000 \mathrm{~Hz}$. It was established by additional investigation that only a slight difference between the reverberation time values is obtained when approximating the sound field muffling $f_{\text {reg }},-3 \mathrm{~dB}$ to $-33 \mathrm{~dB}$ and from $-5 \mathrm{~dB}$ to $-35 \mathrm{~dB}$. 


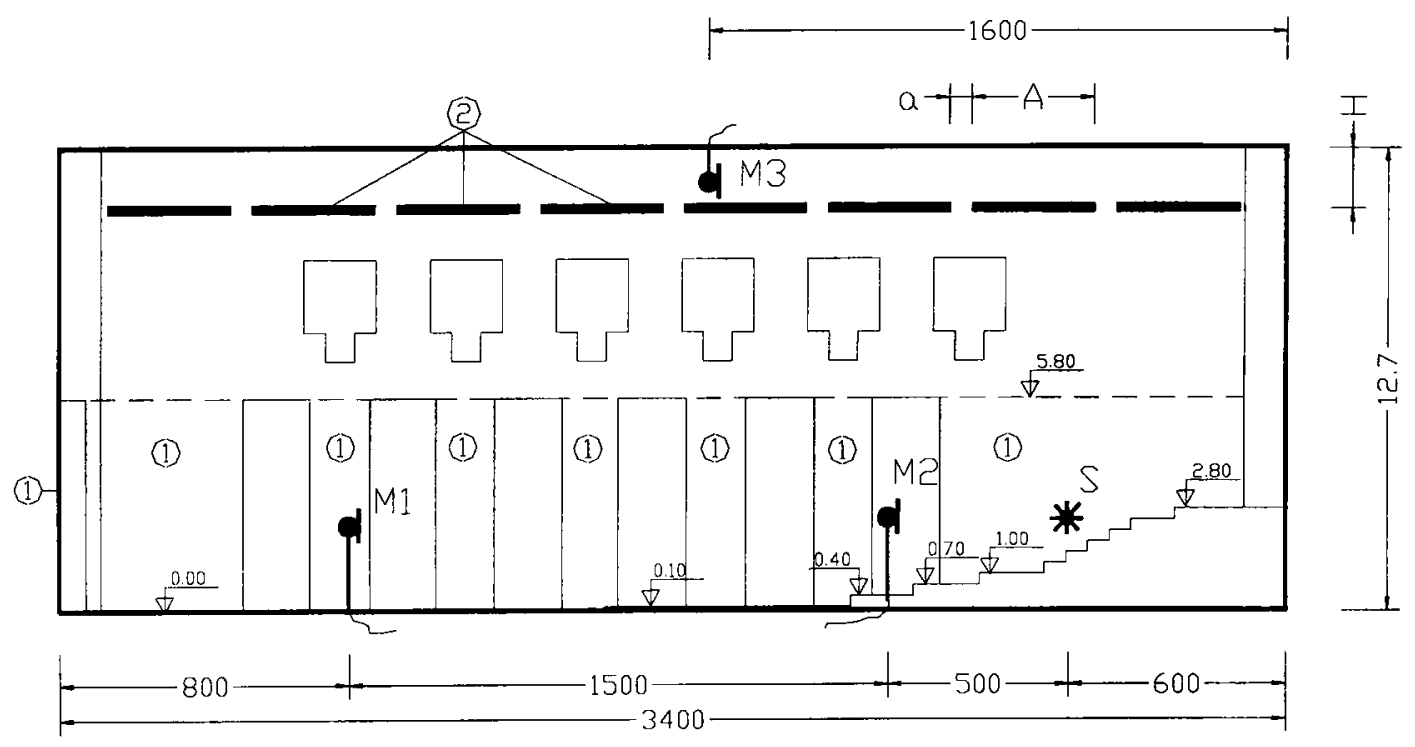

Fig. 1. The longitudinal section of the hall with the resonant suspended ceiling. S - sound source; M1, M2, M3 - positions of microphones; 1 and 2 - points of possible allocation of sound-absorbing materials

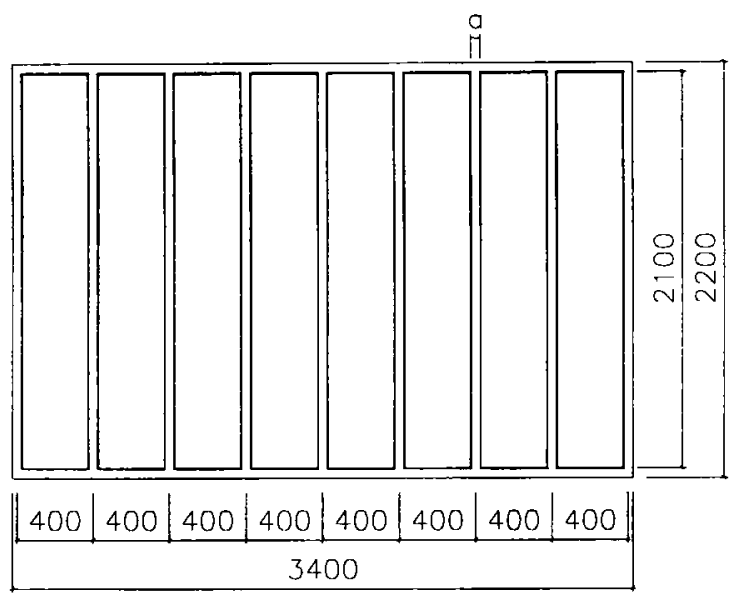

Fig. 2. The lay-out of the suspended ceiling with the rectangular-shaped slits between the planes

In Fig. 3, the results of the reverberation time studies, when the slit width is $50 \mathrm{~cm}$ and the distance to the rigid surface is variable, are presented. In all cases the experiments were conducted at the point 2.

The results of the investigations show that the resonant suspended ceiling markedly reduces the reverberation time at low and medium frequencies. In the hall where no suspended ceiling is installed, the reverberation time is uniformly reduced as frequencies become higher. However, at $160 \mathrm{~Hz}$ the reverberation time is increased by about $1 \mathrm{~s}$ both in the hall without the suspended ceiling and in the hall with such ceiling. This is probably caused by the

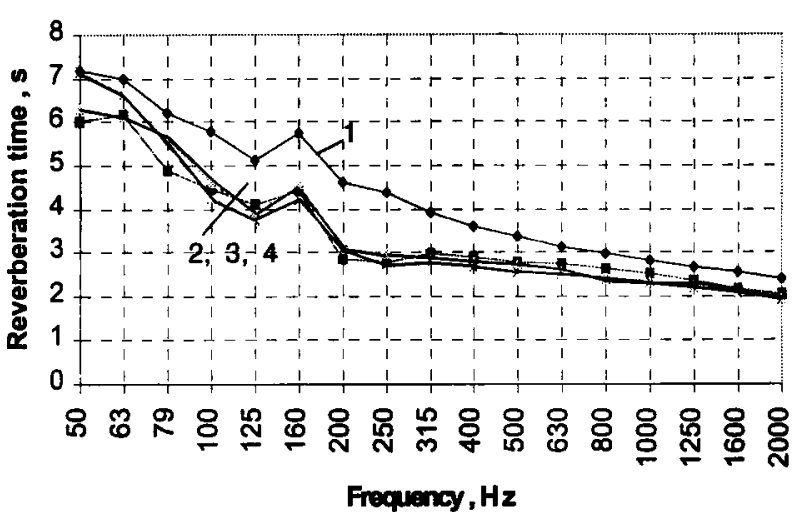

Fig. 3. Frequency characteristics of the hall reverberation time: 1 - without the resonant suspended ceiling; 2 - with the ceiling when the slit width is $100 \mathrm{~cm}$, the distance to the rigid surface $H=100 \mathrm{~cm} ; 3-H=200 \mathrm{~cm} ; 4-H=400$ cm.

hall volume resonances.

Due to the low resolution of the graph it is very inconvenient to analyze the influence of the resonant ceiling on the hall's acoustic indicators from such graph. It is impossible to exactly determine the dependence of these indicators on the geometric parameters of the ceiling. Therefore only relative results will be presented, when the acoustic indicators of the hall without the suspended ceiling are taken as the zero line.

The relative change in the reverberation time depending on the changes in the distance to the rigid surface of the ceiling is depicted in Fig. 4.

The reduction of the reverberation time is the 


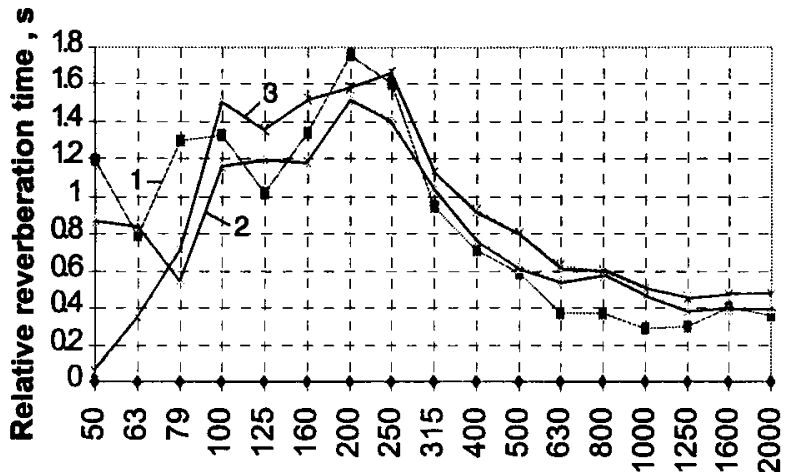

Frequercy, Hz

Fig. 4. The relative dependence of the hall reverberation time on the distance from the resonant suspended ceiling to the rigid ceiling surface. Slit width $100 \mathrm{~cm}$. Zero line corresponds to the case when no suspended ceiling is installed. 1 - distance to the rigid surface $H=100 \mathrm{~cm}$; 2 - $200 \mathrm{~cm} ; 3-400 \mathrm{~cm}$.

greatest when the suspended ceiling is located at the distance of $100 \mathrm{~cm}$ from the rigid surface. The reduction reaches its maximum at $200 \mathrm{~Hz}$ and $250 \mathrm{~Hz}$, amounting to as much as $1.6-1.8 \mathrm{~s}$. At the low frequencies the reverberation time is cut by $0.8-1.3 \mathrm{~s}$ and at the high frequencies the reduction is insignificant - 0.3-0.6 $\mathrm{s}$ only. As the height of the suspended ceiling is increased to $200 \mathrm{~cm}$ and $400 \mathrm{~cm}$, the range of the resonant frequency, at which the greatest reduction is obtained, is expanded. In the range from $125 \mathrm{~Hz}$ to $315-400 \mathrm{~Hz}$, the reverberation time is reduced to $1.6 \mathrm{~s}$ and is little dependent on the height of the ceiling.

The early reverberation time is an important acoustic indicator of the hall. It correlates well with many subjective criteria of evaluation of music sound and is largely dependent on the structure of the early sound reflections. The results of the investigations are presented in Fig. 5.

At the low frequencies the EDT is considerably reduced by the slits in the resonant ceiling. When the height of the ceiling $H$ is $100 \mathrm{~cm}$, the reduction at the low frequencies up to $160 \mathrm{~Hz}$ reaches as much as $2,5 \mathrm{~s}$ and has a resonant character, while at the high frequencies it equals about $0,5 \mathrm{~s}$. When $\mathrm{H}$ is $400 \mathrm{~cm}$, the EDT reduction occupies a broader band of the frequency range.

The relative sound absorption coefficients and the overall sound absorption will be computed from the reverberation time values. The results are presented in Fig. 6.

In this graph, the negative values mean the in-

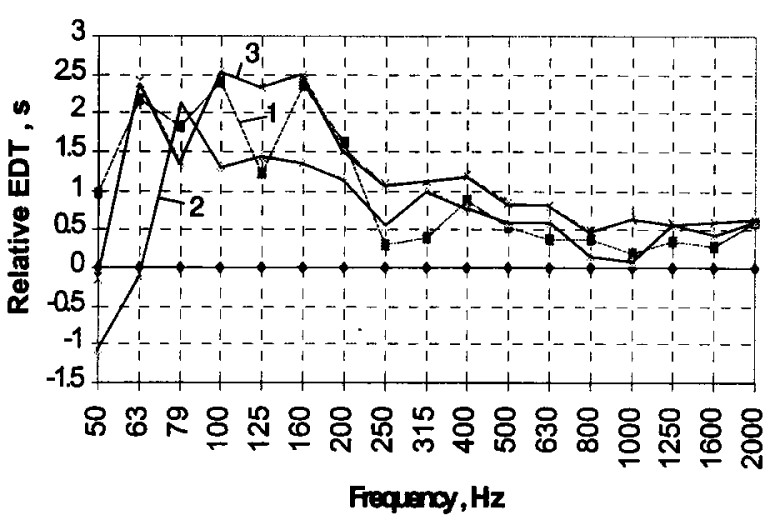

Fig. 5. The relative dependence of the early reverberation time EDT on the distance from the resonant suspended ceiling to the rigid ceiling surface.Slit width 100 $\mathrm{cm}$. The zero line corresponds to the case when no suspended ceiling is installed. 1 - distance to the rigid surface $\mathrm{H}=100 \mathrm{~cm} ; 2-200 \mathrm{~cm} ; 3-400 \mathrm{~cm}$.

crease in the sound absorption coefficient and the positive ones mean the gain in the coefficient. The greatest relative increase in the absorption coefficient is observed at the resonant frequencies of $200 \mathrm{~Hz}$ and $250 \mathrm{~Hz}$ and it equals 0,05 , but only when the height of the suspended ceiling is $100 \mathrm{~cm}$. As this height increases, the coefficient becomes lower throughout the frequency range. When $\mathrm{H}=400 \mathrm{~cm}$, the absorption coefficient even undergoes some decrease at the low and high frequencies.

As noted above, the relative reverberation time is cut to $1,8 \mathrm{~s}$ at the resonant frequencies. In such an event, the sound absorption coefficient should be

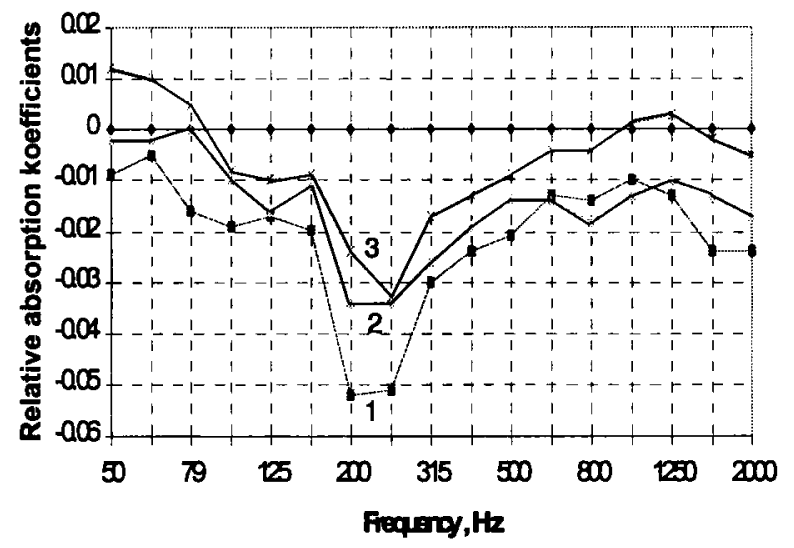

Fig. 6. The relative dependence of the sound absorption coefficients on the distance from the resonant suspended ceiling to the rigid ceiling surface. Slit width $100 \mathrm{~cm}$. The zero line corresponds to the case when no suspended ceiling is installed. 1 - distance to the rigid surface $H=100$ $\mathrm{cm} ; 2$ - $200 \mathrm{~cm} ; 3-400 \mathrm{~cm}$. 
large as well. However, it equals 0,05 only, i.e. is small. When the suspended ceiling is installed in the hall, the absorption coefficients and the absorption itself are computed on the basis of the smaller hall volume and surface areas. These parameters, though larger, were already assessed while computing the acoustic indices of the hall without the suspended ceiling. Thus, the hall volume and the surface areas that are below the suspended ceiling, are evaluated for the second time, whereas the sound energy is only absorbed by the suspended ceiling $748 \mathrm{~m}^{2}$ in area, with the area of the slits making up only 176 $\mathrm{m}^{2}$. Depending on the height of the ceiling, the surface areas assessed in the computations vary from $2790 \mathrm{~m}^{2}$ to $2400 \mathrm{~m}^{2}$. This is exactly the reason for the low relative absorption coefficients obtained.

Based on the sound absorption coefficients, it is easy to determine the value of the sound absorption in the hall with the suspended ceiling. The results of the investigation are presented in Fig. 7.

The character of the change in the sound absorption is similar to that of the sound absorption coefficient. The suspended ceiling installed at the distance of $100 \mathrm{~cm}$ from the rigid surface absorb about $130 \mathrm{~m}^{2}$ of sound energy at the resonant frequencies. It should be noted that the energy is only absorbed by the slits between the planes, without any use of additional sound-absorbing materials.

As the ceiling height increases, the relative absorption is smaller throughout the frequency range, at the resonant frequencies in particular. When the

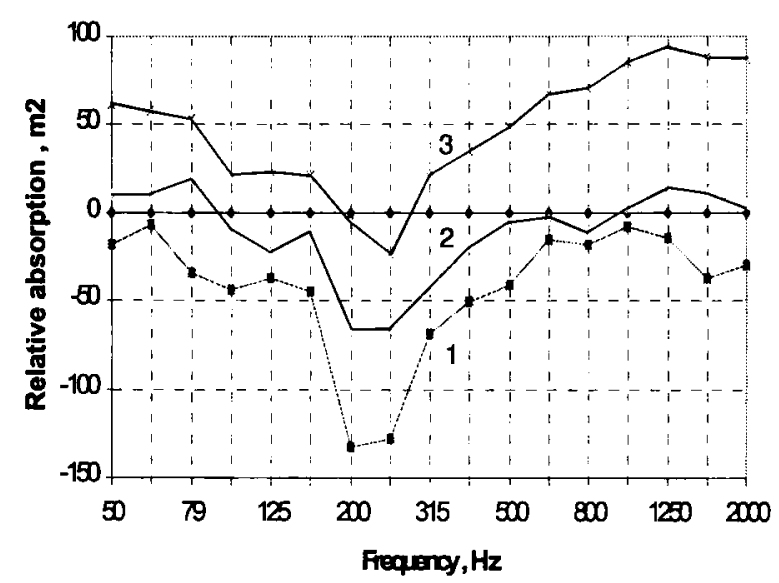

Fig. 7. The relative dependence of the sound absorption on the distance from the resonant suspended ceiling to the rigid ceiling surface. Slit width $100 \mathrm{~cm}$. The zero line corresponds to the case when no suspended ceiling is installed. 1 - distance to the rigid surface $H=100 \mathrm{~cm}$; $2-200 \mathrm{~cm} ; 3-400 \mathrm{~cm}$. height of the ceiling equals $400 \mathrm{~cm}$, the absorption is slightly increased at the resonant frequency, while at all the other frequencies it is not increased but, on the contrary, is reduced to $100 \mathrm{~m}^{2}$, though the reverberation time is also reduced. The result is unexpected, because absorption should become larger along with the reduction of the reverberation time. In this case, however, the phenomenon is determined by the smaller hall volume and surface areas as a result of the increase in the height of the suspended ceiling.

The acoustic centre of gravity shows the frequencies at which the sound energy is maximized. This objective acoustic indicator correlates well with the subjective acoustic indicators. The results of the experiments with the nonfiltered impulse are presented in Fig. 8.

When the suspended ceiling is located $100 \mathrm{~cm}$ from the rigid surface, this indicator increases from $89 \mathrm{~ms}$ the hall without the suspended ceiling to 138 $\mathrm{ms}$, when $H=100 \mathrm{~cm}$. The further increase in the ceiling height results only in a slight increase in the value of this indicator.

The frequency-dependence of the acoustic centre of gravity is presented in Fig. 9.

The results of the investigations show that the acoustic centre of gravity of the hall without the suspended ceiling is uniformly increased along with the increase in frequency and reaches its maximum about $130 \mathrm{~ms}$ at the high frequencies. The value of this indicator is augmented by the suspended ceiling throughout the frequency range. The influence of the increase in the height of the suspended ceiling is insignificant.

The objective acoustic indicators of the hall correlate well with the subjective ones. Clarity of the music sound is one of the most important subjective

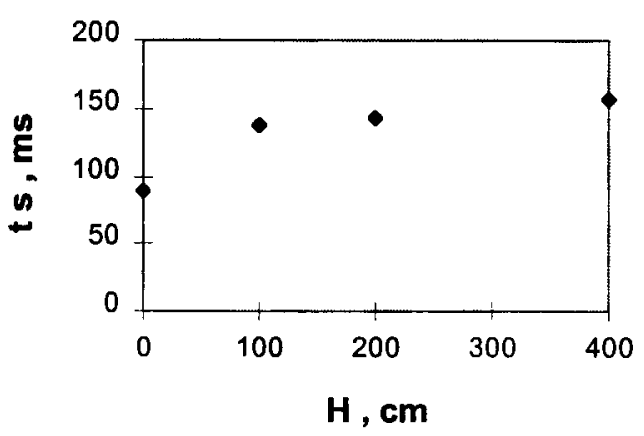

Fig. 8. The dependence of the acoustic centre of gravity on the height of the suspended ceiling $\mathrm{H}$. 


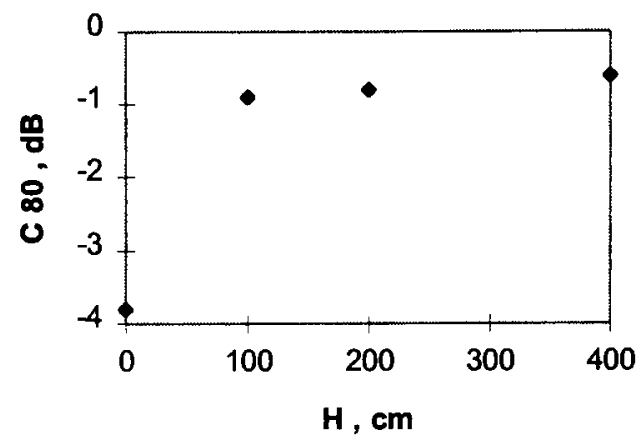

Fig. 9. The dependence of the sound clarity index on the height of the suspended ceiling $H$.

indicators. The results of the experiments with the nonfiltered impulse are shown in Fig. 10.

The graph shows that for the hall without the suspended ceiling this index equals $-3.8 \mathrm{~dB}$. The increase in the height of the ceiling augments this index to $-0.9 \mathrm{~dB}$. The further increase in height does not significantly influence the change in the index.

The frequency-dependence of the clarity index is presented in Fig. 9.

When there is no suspended ceiling in the hall, the clarity index is small at the low frequencies about $10 \mathrm{~dB}$ and is almost independent on frequency. The energy of the reverberation process prevails at these frequencies. The energy ratio undergoes a sharp change at $200 \mathrm{~Hz}$, where this index reaches $-4.5 \mathrm{~dB}$ and does not change much as the frequency increases further. The clarity index is increased by $2-4 \mathrm{~dB}$ throughout the frequency range.

\section{Conclusions}

1. The suspended ceiling with the rectangularshaped slits between the planes reduces the reverberation time to $1.8 \mathrm{~s}$ at the resonant frequencies of $200 \mathrm{~Hz}$ and $250 \mathrm{~Hz}$. The increase in the height of the suspended ceiling is only important at the frequencies up to $160 \mathrm{~Hz}$.

The early reverberation time EDT undergoes the greatest reduction at the low frequencies up to 200 $\mathrm{Hz}$, reaching $2.5 \mathrm{~s}$.

2. The sound absorption coefficient peaks at the resonant frequencies, but only when the height of the ceiling is $100 \mathrm{~cm}$.

3. The hall sound absorption is increased to $\mathbf{1 3 0}$ $\mathrm{m}^{2}$ at the resonant frequencies, but only when the height of the ceiling is $100 \mathrm{~cm}$. As the height of the

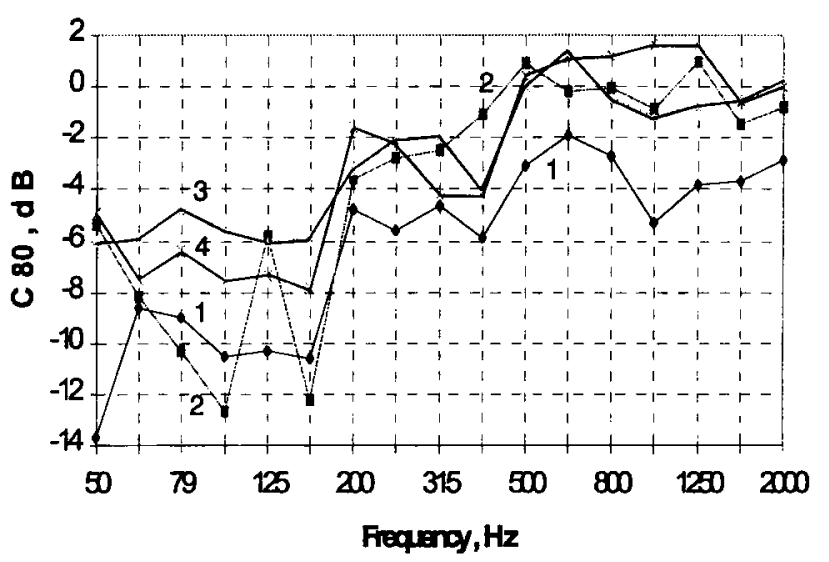

Fig. 10. The dependence of the musical sound's clarity index on on the distance from the resonant suspended ceiling to the rigid ceiling surface.Slit width $100 \mathrm{~cm}$. 1 without resonant ceiling; 2 - distance to the rigid surface $H=100 \mathrm{~cm}: 3-200 \mathrm{~cm}: 4-400 \mathrm{~cm}$.

ceiling increases, the relative absorption is reduced; when the height equals $400 \mathrm{~cm}$, the absorption even diminishes to $60-100 \mathrm{~m}^{2}$ almost over the whole frequency range, when quite the reverse is expected.

4. The sound absorption is determined solely by the resonant suspended ceiling. No additional soundabsorbing materials are used for this purpose.

5. The resonant suspended ceiling influences the acoustic centre of gravity and the music sound clarity index.

\section{References}

1. V. Stauskis. Sound absorption qualities of a cross-shaped isolated acoustic resonator // Acta acustica, Vol. 82(1996), Suppl. 1., p. 264.

2. V. Stauskis. Impedansinis rezonansinių kabamuju lubụ garso absorbcijos skaičiavimo metodas // Statyba (Civil Engineering), V.: Technika, 1996, Nr. 1(5), p. 92-100.

3. V. Stauskis. The sound absorption of an isolated resonator with a cross-shaped slit and its dependence on the number of resonators // Statyba (Civil Engineering), V.: Technika, 1996, Nr. 2(6), p. 50-58.

Iteikta 19961106 


\section{KABAMŲJU REZONANSINIŲ LUBU SU STAČIAKAMPĖS FORMOS PLYŠIAIS ITTAKA SALĖS AKUSTIKAI}

\section{Stauskis}

\section{S a n t r a u k a}

Pateikiami tyrimų rezultatai apie rezonansiniu kabamujy lubų su stačiakampés formos plyšiais tarp plokštumu jtaką salès reverberacijos laikui, garso absorbcijos koeficientams ir absorbcijai, akustiniam svorio centrui ir muzikos skambejimo skaidrumo indeksui.

Tyrimai atlikti fiziniame salès modelyje (mastelis 1:25).

Rezonansinès lubos su $100 \mathrm{~cm}$ pločio stačiakampiais plyšiais tarp plokštumu, kurie yra $100 \mathrm{~cm}$ atstumu nuo standaus paviršiaus, reverberacijos laiką, esant rezonansiniams dažniams 200 ir $250 \mathrm{~Hz}$, sumažina 1,8 sekundès, ir apie 1,2 sekundès esant žemesniems dažniams. Esant aukštiems dažniams šis sumažejimas nedidelis ir siekia apie 0,5 s. Kabamuju lubu aukščio didejimas turi nedidelés įtakos tik esant žemiems dažniams.

Ankstyvas reverberacijos laikas EDT diapazone 50-200 $\mathrm{Hz}$ sumažeja 1,5-2,5 s, o esant aukštesniems dažniams jis yra nedidelis.
Garso absorbcijos koeficientai daugiausiai padidèja esant rezonansiniams dažniams 200 ir $250 \mathrm{~Hz}$. Tada, kai kabamuju lubu aukštis yra $100 \mathrm{~cm}$, salès garso absorbcija padideja iki $140 \mathrm{~m}^{2}$. Kai lubu aukštis yra $400 \mathrm{~cm}$, tai absorbcija ne padideja, o sumažèja, nors turètụ būti atvirkščiai. Paaiškinamos šio reiškinio priežastys.

Dideliems reverberacijos laiko ir garso absorbcijos pokyčiams turi ịtakos vien tik plyšiai tarp plokštumų. Jokiu papildomy absorbuojančiu medžiagu tam nèra naudojama.

Rezonansinès lubos su stačiakampès formos plyšiais turi itakos akustiniam svorio centrui ir skaidrumo indeksui C 80 .

Vytautas STAUSKIS. Doctor, Associate Professor. Department of Building Structures. Vilnius Technical University, 11 Saulètekio Ave, LT-2040 Vilnius, Lithuania. In 1974 a thesis in technical science. From 1974 at VTU Department of Building Structures as assistant, Master of science. Scientific visits: Moscow Civil Engineering Institute, Sankt-Peterburg Politechnical Institute. Research interests: experimental testing of halls by primary hall models and on site, computer simulation of theoretic tasks, wave diffraction and reflections, direct sound and subjective acoustic indicators, large-dimension resonance structures, early attenuation of acoustic field and its relation to hall acoustics. 